DOI: $10.4274 /$ tpa.45.132

\title{
Sivas il merkezinde yaşayan ilkokul birinci sınıf öğrencisi çocuklarda hepatit B ve hepatit C yaygınlığı
}

\section{Prevalence of hepatitis B and C in first grade primary school children living in Sivas, Turkey}

\author{
Adnan Ayvaz, Naim Nur*, Aynur Engin** ${ }^{*}$, Selma Çetinkaya*** \\ Cumhuriyet Üniversitesi Tıp Fakültesi, Çocuk Sağlığı ve Hastalıkları Anabilim Dalı, Sivas, Türkiye \\ ${ }^{*}$ Cumhuriyet Üniversitesi Tıp Fakültesi, Halk Sağlığı Anabilim Dalı, Sivas, Türkiye \\ ${ }^{*}$ Cumhuriyet Üniversitesi Tıp Fakültesi, Enfeksiyon Hastalıkları ve Klinik Mikrobiyoloji Anabilim Dalı, Sivas, Türkiye \\ ${ }^{* * *}$ Cumhuriyet Üniversitesi Tıp Fakültesi, Tıp Eğitimi Anabilim Dalı, Sivas, Türkiye
}

\section{Özet}

Amaç: Bu çalışma, ülkemizde genel hepatit B aşılamasının başlamasından sonra çocukların ne kadarının aşılandığını ve aşılanan çocukların ne kadarının bağışıklık geliştirdiğini belirlemek, hepatit B ile enfekte veya taşıyıcı olanları tespit etmek ve ek olarak hepatit C yaygınlığını göstermek amacıyla yapılmıştır.

Gereç ve Yöntem: Bu çalışma, Sivas il merkezindeki ilköğretim okullarının birinci sınıfında bulunan yedi yaşındaki çocuklarda yapılan kesitsel bir araştırmadır. Çocuklardan alınan venöz kan örneklerinde ELiSA (Enzyme-linked immunosorbent assay) yöntemi ile HBsAg, AntiHBs, anti-HCV, anti-HBc IgG ve IgM bakılmıştır.

Bulgular: Çalışmaya alınan 607 çocuktan 301'i (\%49,6) kız, 306'sı (\%50,4) erkekti. Anti-HBs (+) olan çocukların sayısı 449 (\%73,9), antiHBs (-) olanların sayısı $158(\% 26,1)$ idi. HBsAg ve anti-HCV için \%0,16 yaygınlık değerleri elde edildi.

Çıkarımlar: Bölgemizde HBsAg ve anti-HCV yaygınlığının beklenenden düşük bulunması bize sağlık hizmetlerinde başarılı çalıșmalarla ülkemizdeki viral hepatit yaygınlığının gelişmiş ülkelerdeki seviyelere indirilebileceğini düşündürmektedir. (Türk Ped Arş 2010; 45: 132-6)

Anahtar sözcükler: Aşılama, çocuk, hepatit B, hepatit C, yaygınlık (prevalans)

\section{Summary}

Aim: The aim of this study is to determine the portion of children vaccinated against HBV and immunized to HBV after vaccination program was started in Turkey, to detect infected children with HBV or carriers, and to show the prevalence of HCV in the children.

Material and Method: The study is a cross-sectional research which was carried out to seven-year-old children from the 1st grades of primary schools in Sivas city center. Venous serum specimens obtained from the children were tested for anti-HBc lg G and M, HBsAg, anti-HBs and anti-HCV by using a commercially available enzyme-linked immunosorbent assay (ELiSA).

Results: Of 607 children, 301 (49.6\%) were females and $306(50.4 \%)$ were males. The numbers of the children who were anti-HBs (+) were 449 (73.9\%), anti-HBs (-) were $158(26.1 \%)$. It was found that the prevalences of HBsAg and HCV were $0.16 \%$.

Conclusions: Since the prevalences of HBsAg and HCV were found lower in our study than the expected, we are in the opinion that with successful efforts in the health services, the spread of viral hepatitis in our country can be dropped to the levels of the countries which have low levels. (Turk Arch Ped 2010; 45: 132-6)

Key words: Children, hepatitis B, hepatitis C, prevalence, vaccination

\section{Giriş}

Her yıl yaklaşık bir milyondan fazla kişi siroz, hepatoselüler karsinoma dahil hepatit $B$ virüsüne bağlı karaciğer hastalıkları nedeniyle kaybedilmektedir $(1,2)$.
Ülkemizin de içinde bulunduğu ve orta endemik özelliğe sahip bölgelerde HBsAg pozitifliği \%2-5 arasında değişmektedir. Enfeksiyon daha çok çocukluk çağlarında görülmektedir ve ana bulaşma yolu enfekte anneden bebeğe geçiş şeklindedir $(2,3)$. Hiçbir klinik bulgusu olmayan

Yazışma Adresi/Address for Correspondence: Dr. Adnan Ayvaz, Cumhuriyet Üniversitesi Tıp Fakültesi, Çocuk Sağlığı ve Hastalıkları Anabilim Dalı, Sivas, Türkiye E-posta adnanayvaz@yahoo.com

Geliş Tarihi/Received: 02.12.2009 Tarihi/Accepted: 22.03.2010 
HBsAg taşıyıcısı annelerden doğan bebekler, tedavi edilmezlerse \%65-90 arası oranlarda kronik HBsAg taşıyıcısı olabilirler ve yaşamlarının ilerleyen dönemlerinde yüksek oranda kronik hepatit ve hepatoselüler karsinoma riski ile karşı karşıya kalırlar $(1,4)$.

Dünyanın birçok ülkesinde Dünya Sağlık Örgütü (DSÖ) önerisiyle uygulanmakta olan evrensel hepatit B aşılama programına Türkiye 1998'den itibaren katılmıştır (5). Ülkemizde sağlık çalışanlarının gayretine rağmen hepatit $B$ aşılamasında hala bazı aksaklıklar görülmekte ve verimlilik düşük olmaktadır (6).

Hepatit C virüs (HCV) enfeksiyonu yaygınlığı diğer viral hepatitlere göre daha az, ancak kronikleşme riski daha fazladır. Ülkemizde tüm dünyada olduğu gibi yaygınlığı daha çok kan verici taramaları ile araştırımaktadır. Buna göre toplumda anti-HCV pozitifliği son 16 yılın verileri göz önüne alındığında \%0,38'dir ve yıllar arasında anlamlı bir farklılık olmadığı bildirilmektedir (7).

Bu çalışmanın amacı, ülkemizde hepatit B aşılamasının başlamasından sonra aşılanan ve bağışıklık geliştiren çocukların oranını belirlemek, hasta veya taşıyıcı olanları tespit etmek ve çocuk yaş grubunda HCV yaygınlığın göstermektir.

\section{Gereç ve Yöntem}

Çalışma 01.05.2008-30.06.2008 tarihleri arasında, Sivas il merkez ilköğretim okullarının 1. sınıfında olan yedi yaşındaki çocuklarda gerçekleştirilmiş kesitsel bir araştırmadır. Araştırma evrenini toplam 5635 çocuk oluşturmaktadır. Sistematik örnekleme yöntemiyle $(\alpha=0,05$, $d=0,04, p=0,05, q=0,95, N=5635$ ) örneğe seçilen çocuk sayısı belirlendikten sonra rastgele sayılar tablosu yardımıyla 12 okul araştırma için seçildi. Çalışma kapsamına alınan 627 kișinin 607'sine (\%95,3) ulașıldı.

Çocukların ailelerinden yazılı onay alındı. Velilerin kendi doldurdukları bir anket formunda cinsiyet, anne babanın iși, eğitimi, gelir düzeyi gibi sosyo-demografik özellikleri yer aldı. Hepatit $B$ așılama durumu, aile bireylerinde hepatit B, C öyküsü, diş çekimi, kan transfüzyonu, operasyon olup olmadığı kaydedildi.

Çocuklardan alınan kan örneklerinde anti-HBc IgG ve IgM, HBsAg ve anti-HBs, anti-HCV antikoru ELiZA (Enzyme-linked immunosorbent assay) yöntemi ile bakıldı. Test sonuçları ve yorumları çalışma sonucunda her çocuk için ayrı olarak, önerilerimizle birlikte ailelerine kapalı zarf içinde bildirildi.

Verilerin incelenmesi SPSS 14,0 paket programında yapıldı. Sonuçlar sayı ve yüzde olarak ifade edildi. Karşılaştırmalarda ki kare testi kullanıldı. $\mathrm{p}<0,05$ olan değerler istatistiksel olarak anlamlı kabul edildi.

Çalışma Cumhuriyet Üniversitesi etik kurulu tarafından 2007-6/6 onay numarasıyla onaylanmıștır.

\section{Bulgular}

Çalışma grubunda kan örnekleri incelenerek sonuçları değerlendirilen 607 çocuğun 301'i $(\% 49,6)$ kız, 306'sı $(\% 50,4)$ erkekti.

Anti-HBs (+) pozitif olan çocukların sayısı $449(\% 73,9)$, anti-HBs (-) negatif olanların sayısı $158(\% 26,1)$ idi. AntiHBs (+), HBsAg (-) olan çocuklardan aşlı olduğu belirtilenlerin sayısı $362(\% 59,6)$, aşı yapılıp yapılmadığı bilinmeyenlerin sayısı $54(\% 8,8)$, aşısı olmayanların sayısı 33 $(\% 5,4)$ idi.

Anti-HBs (-) olan çocuklardan HBsAg (+) olan sadece bir çocuk vardı $(\% 0,16)$. Bu çocukta anti-HBc IgG pozitif, anti-HBc IgM düzeyi negatifti. Hepatit aşısı yapılmadığı, kan nakli ve diş tedavisi yaptırdığı, annesinin ve abisinin HBsAg (+), anti-HBs (-) olduğu anket formundan öğrenildi. Herhangi bir yakınması ve bulgusu olmayan bu çocukta AST: $16 \mathrm{U} / \mathrm{L}$ (0-31), ALT: $13 \mathrm{U} / \mathrm{L}(0-34)$ idi. HBsAg negatif olan diğer çocuklarda $(\% 99,84)$ anti-HBc IgG ve anti-HBc IgM düzeyleri negatif bulundu.

Anti-HBs ve HBsAg (-) olan çocukların sayısı $157(\% 25,8)$ idi. Bu çocukların 27 'sinin $(\% 4,4)$ aileleri hepatit B aşı durumunu bilmediklerini, 124'ünün ailesi $(\% 20,4)$ aşı yapıldığını, altısının (\%1) ailesi ise hiç aşı yapılmadığını bildirdiler.

Bir çocukta anti-HCV antikoru (+) bulundu $(\% 0,16)$. Bu çocuğun fizik muayenesi, hemogramı ile kan transaminazları (ALT, AST) normaldi ve PCR yöntemi ile HCV-RNA değeri (-) olarak saptandı. Anket formundan hepatit B aşılarının yapıldığı ve viral bulaş risk etmenlerinden hiçbirini taşımadığı öğrenildi. Diğer bir çocukta anti-HCV antikoru şüpheli pozitif (+/-) çıkınca test tekrarlandı ve negatif bulundu.

Anket formlarına göre, en az bir kez HBV aşısı olan çocukların toplam sayısı $486(\% 80,0)$ idi. Bu çocukların 362 'sinde $(\% 59,6)$ anti-HBs (+) idi. Toplam içinde aşı öyküsü bilinmeyenlerin sayısı $81(\% 13,3)$, hiç aşı yapılmadığı bildirilenlerin sayısı ise $40(\% 6,5)$ idi. Ebeveynler anket formlarında çocukların ilk hepatit aşısının \%27,9'unun doğumda, \%12,7'sinin 1. ayda, \%14,6'sının 2. ayda, $\% 15,4$ 'ünün 3. ayda ve \%20,0'sinin diğer zamanlarda yapıldığını belirttiler. Ebeveynlerin \%31,9'u çocuğuna üç doz, \%16,1'i iki doz ve \%28,1'i bir doz aşı yapıldığını bildirdi.

Hepatit bulaşmasında olası risk etmenleri araştırıldığında; \%39,3'ünde diş tedavisi, \%19,9'unda ailede sarılık, \%19,4'ünde operasyon ve $\% 8,8$ 'inde kan nakli öyküsü tespit edildi.

\section{Tartışma}

Toplumda sosyoekonomik şartların, sağlık eğitiminin artırıması yanında viral hepatitlerle mücadelede en etkin yollardan biri aşılamadır. Aşılama ilk olarak hedef kitle seçilen risk grupları üzerinde başlatılmasına rağmen bu yöntem ile düşük endemik bölgelerde bile yeterli enfeksiyon 
kontrolü sağlanamamıştır. Hepatit B virüs bulaşmasında \%30-40 olguda enfeksiyon kaynağı bilinememektedir (8). Bu deneyimler sonucunda DSÖ, HBV aşılamasının gelişmekte olan ülkeler için ulusal aşı programına alınmasını önermiştir.

Evrensel HBV aşılamasının temel amacı, olası hepatit B taşıyıcısı annelerin bebeklerinin olabildiğince erken bağışıklanmasıdır. Gebelerin HBsAg yönünden taranmadığı ülkemizde bu konunun önemi büyüktür. Ancak her ne kadar yayınlanan genelgede HBV aşılamasının doğumdan itibaren uygulanmasının önemi vurgulanmışsa da ülkemiz koşullarında her yenidoğan bebeğe doğumdan sonraki ilk günlerde ulaşmak her zaman mümkün olamamaktadır. Çalışmamızda da HBsAg pozitif (+) olan tek çocuğun anti-HBs negatif (-), anti-HBc IgG (+), anti-HBc lg M (-), HBeAg (-) olması nedeniyle HBs tașıyıcısı olduğu düșünüldü (9). Ebeveynleri doğumda aşı yapılmadığını belirttikleri için virüsü olasılıkla doğumda annesinden aldığı düşünülmektedir. Tosun ve ark.'larının (10) 2003 yılındaki çalışmalarında sağlık ocağında 255 bebekten sadece ikisinin ilk gün aşılandığı $(\% 0,78), \% 56$ 'sının ise ikinci ay ve sonrasında aşılandığı belirtilmiştir. Bizim çalışmamızda çocukların ilk hepatit aşısının \%27,9'unun doğumda, \%12,7'sinin 1. ayda, \%14,6'sının 2. ayda, \%15,4'ünün 3. ayda ve \%20,0'sinin diğer zamanlarda yapıldığı görülmektedir. Bir başka çalışmada Tosun ve ark.'ları (11), bir merkez sağlık ocağı bölgesinde 1998 yılında tam aşılandıktan dört yıl sonra 76 çocuktan 65 'inde $(\% 86,8)$ yeterli düzeyde anti-HBs antikoru geliştiğini tespit ederek yayınlamıştır. Geçen zaman içinde evrensel HBV aşı uygulamasının giderek daha benimsendiği ve uygulamanın yaygınlaştığı ancak doğumda çocukların hepsinin aşılanmadığı fark edilmektedir.

Bölgemizde daha önce çocuklarda yapılmış bir hepatit göstergeleri tarama çalışması yoktur. Genel toplumda 1995 yılında bölgemizde yapılan bir çalışmada HBsAg pozitifliği \%7,5, anti-HBs pozitifliği \%27,5 bulunmuştur (12). Çalışmamızdaki HBsAg pozitifliğinin düşüklüğü $(\% 0,16)$ HBV aşılamasının bölgemizde zaman içinde daha yaygın uygulanmasının sonucu olabilir.

T.C. Sağlık Bakanlığına 2003 yılında bildirilen hepatit B olgularının oranı 0-14 yaş arasında \%0,28-4,75 arasında değişmekte, çalışma grubumuzla benzer olan 5-9 yaş arası çocuklarda ise \%4,0 olarak görülmektedir (7). Çalışmamızın sonuçlarına göre HBsAg pozitifliği \%0,16'dır. Bu rakamlar genellikle devletin sağlık kuruluşlarından düzenli istatistiki veri olarak alınmış verici, hasta veya hastalık şüphesi olan bireylerden elde edilmiş örneklerin sonuçlarıdır. Genel hepatit B aşılamasının başlamasından dört yıl sonra bile rakamlar oldukça yüksektir.

Ülkemizde şehirler arasında sosyokültürel düzey farkıılıkları ile açıklanabilecek oldukça farklı HBsAg pozitiflik oranları söz konusudur. Şanlıurfa yöresinde 2 ay 15 yaş arasındaki çocuklarda yapılan bir çalışmada bu oran \%12,5 olarak bildirilmiştir (13). Erzurum'da 2003 yılında yapılan bir çalışmada 6-17 yaş arası çocuklarda HBsAg pozitifliği \%1,8, 2004'de yayınlanan bir başka çalışmada 0-18 yaş arasındaki çocuklarda HBsAg pozitifliği \%1,7 ve anti-HBs pozitiflik oranı \%39,4 olarak tespit edilmiştir $(14,15)$. Van'da 2000 yılında HBsAg pozitifliği \%9,8 iken, 2005'de yapılan başka bir çalışmada \%9,5 bulunmuştur $(7,16)$. Gaziantep'te 2003 yılında ilkokul öğrencilerinde HBsAg pozitifliği \%3,0 iken 2005 yılında altı yaş altı çocuklarda HBsAg pozitifliği \%1,25, anti-HBs pozitiflik oranı \%70,8 bulunmuş, bunlardan \%54,7'sinin aşılı olduğu belirtilmiştir $(17,18)$. Çalışmamızda anti-HBs pozitiflik oranı \%73,9 idi ve bu çocuklarda HBsAg (-), anti HBc IgG (-) olduğu için bu bağışıklıklarının aşılamaya bağlı olduğu kabul edildi. Çalışmamızda doğal bağışık [anti-HBs (+), HBsAg (-), anti HBc lgG (+)] olan çocuk tespit edilmedi.

Anket formlarına göre \%80,0'i $(n=486)$ hepatit B aşısı yapılan çocukların \%74,4'ünde $(n=362)$ seropozitiflik gelişmiş olduğu görüldü. Anti-HBs (+) olan çocukların 54'ünde aşı öyküsü bilinmiyor, 33'ü de aşı yaptırmadığını belirtiyordu. Anti-HBs (+) 449 çocuktaki bağışıklığın sonuçlarımıza göre aşılamaya bağlı olduğu bilindiği için, aşılama öykülerinin güvenilir olmadığı, çocukların aşılanmış olabileceği ve aşıya bağlı seropozitiflik oranının daha yüksek olabileceği tahmin edilebilir.

HBsAg (-), anti-HBs (-) olan 157 çocuğun 124'ü $(\% 78,9)$ aşılıdır. Bu çocuklarda zaman içinde anti-HBs düzeylerinin azaldığı düşünülebilir. Aşı yapılan 486 çocuktan seropozitiflik görülmeyen ya da anti-HBs düzeyleri azalan 37 çocuğun da $(\% 7,6)$ anti-HBs negatif olsa bile anamnestik yanıt geliştirebileceği düşünüldü. Bu durumu gösterebilmek için bir doz hepatit aşısı yapıldıktan 2-4 hafta sonra anti-HBs düzeylerinin anamnestik artışının ölçümü gerekmektedir (2). Çocukların aşılama öyküleri aşı kartları, sağlık ocağı kayıtları gibi kesin verilere değil ebeveynlerin anket sorularımıza verdikleri cevaba dayanmaktadır. Bu nedenle aşı öykülerinin güvenirliliği tartışmalı olmakla birlikte bu konuda yine de fikir vermektedir.

HBV aşısı ile en az bir kez aşılı olan çocukların toplam sayısı 486 (\%80,0), anti-HBs (+) olan çocukların sayısının 449 (aşılı olanlara göre oranı \%92,3) olduğu göz önünde bulundurulursa yapılan hepatit B aşılamasının etkin olduğu sonucuna varılabilir.

Dünya üzerinde çocukluk yaş grubunda HBsAg pozitiflik oranları yüksek yaygınlığa sahip ülkelerden Moğolistan'da \%7,5 (2007), Pakistan'da \%2,4 (2009), Tayvan'da \%1,05 (2006), orta yaygınlığa sahip ülkelerden Arabistan'da \%1,7 (2008) olduğu yayınlanmıştır (19-22). Belçika'da 1993 ve 2003 yıllarında yapılan yaygınlık çalışmalarında HBsAg pozitiflik oranlarının (sırasıyla \%0,7 ve \%0,66) yıllar içinde azaldığı görülmektedir (23). Çalışmamıza uygun düzenekte Arabistan'da aynı bakış açısıyla yola çıkılan, evrensel HBV aşılaması başlatıldıktan 8 yıl sonra yapılan seroepidemiyolojk çalışmada 1-12 yaş arası 4791 çocukta HBsAg pozitiflik oranı \%0,31 (doğumda 
aşılanmış olanlarda \%0,16, okul öncesi aşılananlarda $\% 0,7)$ bulunmuştur. Ayrıca bu oranların 1989'da \%6,7 iken 1997'de \%0,3'e düştüğü vurgulanmıştır (24). Yıllar içinde evrensel aşı uygulamasının Dünya üzerinde yaygınlaşması ile aşılamanın etkili olduğu ve çocuklar arasında HBsAg pozitiflik oranlarının azaldığı görülmektedir (2).

Anti HCV antikoru pozitif olan sadece bir çocuk tespit edildi $(\% 0,16)$. Bulgusu olmayan bu çocuğun yapılan tetkik sonuçlarında PCR yöntemi ile HCV-RNA (-), karaciğer enzimleri normal düzeylerdeydi. Tedavi önerilmedi, ancak düzenli aralıklarla kontrollere çağrıldı.

Hepatit C enfeksiyonu ülkemizde tüm dünyada olduğu gibi yaygınlığı daha çok kan verici taramaları ile araştırılmaktadır. Bölgemizde 2001 ve 2004 yıllarında yapılan iki farklı çalışmada 12954 vericide anti-HCV pozitifliği \%0,8, 38885 vericide \%0,3 bulunmuştur $(25,26)$. Yine bölgemizde 1995 yılında kan vericisi olmayan genel toplumda yapılan bir başka çalışmada ise anti-HCV pozitifliği \%4,2 bulunmuştur (12). Bu çalışmalar çocukluk yaş grubunda yapılmadığından, çalışmamızın sonuçları ile tam olarak kıyaslanamaz. Ancak bölgemizdeki çocuklarda anti-HCV pozitiflik oranının $(\% 0,16)$ her üç çalışmadaki sonuçlardan düşük olduğu hakkında fikir verebilir.

Ülkemizde çeşitli şehirlerde çocukluk yaş grubunda yapılan bazı çalışmalarda anti-HCV pozitiflik oranları şöyledir: Adana'da 10 yaş üstü çocuklarda \%0,7, Ankara'da 11-15 yaş çocuklarda \%1,4, Elazığ'da 7-14 yaş çocuklarda \%0,0, Malatya'da 0-12 yaş çocuklarda \%1,2, Eskişehir'de 0-18 yaş çocuklarda \%0,9, Erzurum'da 2-12 yaş çocuklarda \%0,5 bulunmuştur (27-32). Bu çalışmalarda bakılan örnek sayıları benzer yaş gruplarında ortalama 425 (194-656) olup çalışmamızdaki örnek sayısı bu ortalamanın üzerindedir $(n=607)$. Daha fazla örnek sayısı ile bakılan çalışmamızın anti-HCV pozitiflik oranının $(\% 0,16)$ bölgemizdeki çocuklarda oldukça düşük bulunması sevindiricidir.

Dünya üzerinde çocukluk yaş grubunda anti-HCV pozitifliği açısından bazı ülkelerde oranlar şöyledir: Moğolistan'da \%5,4 (2007), Pakistan'da \%2,1 (2009), Tayvan'da $\% 2,11$ (2006), Arabistan'da \%0,0 (2008) bulunmuştur (19-22). Hepatit B ve C açısından yüksek yaygınlığa sahip Tayvan'da 2008 yılında yapılan bir başka yaygınlık çalışmasında yerli ve şehirli çocukların anti-HCV pozitifliği bakılmış, yerlilerde \%0,3 ( $n=4 / 1176)$ şehir çocuklarında ( $n=0 / 606$ ) bulunmuştur (33). Belçika'da hastaneye başvuranlarda farklı zamanlarda yapılan iki çalışmada dörtte biri 20 yaş altı olan çeşitli yaş gruplarında anti-HCV pozitifliği 1993'de \%0,87 iken 2003'de \%0,12 bulunmuştur (23).

Sonuç olarak yedi yaşındaki ilköğretim birinci sınıf öğrencileri arasında yaptığımız çalışmada HBsAg $(\% 0,16)$, anti-HCV $(\% 0,16)$ oranlarının beklenenden düşük bulunması hepatit enfeksiyonları ile mücadelede evrensel aşılamanın oldukça etkili olduğunu ve bölgemizin sosyoekonomik düzeyinin çok yüksek olmamasına rağmen bu konudaki sağlık çalışmalarının iyi sonuçlar verdiğini düşündürmektedir. Bu çalışmada olgu sayısının yetersizliği nedeniyle analitik çıkarım yapılamamıştır. Ancak tartışma bir ilin ilkokul birinci sınıf düzeyinde tüm öğrencilerini temsil eder bir örneklemle kurgulandığı ve alan temsil yeteneği olduğu için tanımlayıcı boyutuyla önemlidir.
Türkiye'nin Orta Anadolu bölgesinde yer alan Sivas ilinde yaptığımız bu çalışma ülkedeki hepatit yaygınlığını birebir yansıtmamakla birlikte viral hepatitlerin yaygınlığının sağlık alanındaki başarılı çalışmalar sonucunda gelişmiş ülkelerdeki seviyelere ulaşabileceği düşüncesini oluşturmuştur. Evrensel HBV aşılamasının başlatılmasından yaklaşık on yıl sonra diğer bölgelerimizde benzer şekilde yapılacak saha çalışmaları ülkemizin Dünya üzerindeki yaygınlık seviyesinin daha düşük olduğunu gösterebilir.

\section{Teşekkür}

Çalışmamıza katkılarından dolayı Op. Dr. Osman Yıldızlar'a, Prof. Dr. Zahir Bakıcı ve ekibine, çalışma kapsamında yer alan ilköğretim okullarının öğretmenleri ile yöneticilerine, kan alma işlemleri sırasında çocuklara karşı sevecen ve becerikli davranarak çalışmayı kolaylaştıran hemşirelerimize ve intern öğrencilerimize teşekkür ederiz.

\section{Kaynaklar}

1. Alter MJ. Epidemiology of hepatitis B in Europe and worldwide. J Hepatol 2003; 39: 64-9.

2. Badur S. Hepatit B enfeksiyonları: epidemiyoloji ve aşı. Klinik Gelişim Dergisi 2005; 18: 32-43.

3. Lavanchy D. Hepatitis virus epidemiology, disease burden, treatment and current and emerging prevention and control. $J$ Viral Hepat 2004; 11: 97-107. (Abstract) / (Full Text) / (PDF)

4. Harma M, Harma M, Kafalı H, Güngen N, Demir N. Gebelerde hepatit B taşıyıcılığı ve yenidoğana vertikal geçiş. Perinatoloji Dergisi 2003; 11: 29-32. (Full Text) / (PDF)

5. T.C. Sağlık Bakanlığı Temel Sağlık Hizmetleri Genel Müdürlüğü. Hepatit B hakkında genelge. 6856/ 04.06.1998.

6. Tosun YS, Erdurak K, Ertekin E. Ülkemiz koşullarında üniversal hepatit B aşılaması nasıl daha etkin, daha yaygın ve daha ekonomik uygulanabilir? T Klin Pediatri 2003; 12: 30-5. (Abstract) / (PDF)

7. Mıstık R. Türkiye'de viral hepatit epidemiyolojisi yayınların irdelenmesi. İçinde: Tabak F, Balık I, Tekeli E (yazarlar). Viral Hepatit 2007. İstanbul: Oban Matbaası, 2007: 9-51.

8. Özgenç F. Viral hepatit așıları. Türkiye Klinikleri J Pediatr Sci 2007; 3; 65-9. (Abstract) / (PDF)

9. Özsan M. HBV enfeksiyonunda mikrobiyolojik tanı. İçinde: Tabak F, Balık I, Tekeli (yazarlar). Viral Hepatit 2007. İstanbul: Oban Matbaası, 2007:127-9.

10. Tosun YS, Karaca M, Kasırga M. Ülkemizde uygulanan universal hepatit B aşılama șeması yeterli mi? Sürekli Tıp Eğitimi Dergisi 2003;12: 6-7. (PDF)

11. Tosun YS, Eser E, Sır E, Bayındırı D, İrençin D, Obalı C.. Manisa ili Muradiye sağlık ocağı merkez bölgesinde 1998 yılında hepatit $B$ aşılama programına alınan çocuklarda dört yıl sonraki aşı koruyuculuk düzeyi araştırması. MN Klinik Bilimler \& Doktor 2003; 9: 459-66. (Abstract)

12. Poyraz Ö, Sümer H, Öztop $Y$, Saygı G, Sümer Z. Sivas yöresinde genel toplumda hepatit $A, B$ ve $C$ virüs belirleyicilerinin araştırılması. İnfeksiyon Dergisi 1995; 9: 175-8. (Abstract)

13. Kösecik M, Emiroğlu H, Tatı MM, Koçyiğit A, Ö Erel, Ataş A. Şanlıurfa yöresindeki çocuklarda asemptomatik hepatitis $B$ virüs tașıyıcılığı prevalansı. Türk Pediatri Arşivi 1998; 33: 106-9. (Abstract)

14. Ertekin V, Selimoğlu MA, Altınkaynak S. Sero-epidemiology of hepatitis $B$ infection in an urban paediatric population in Turkey. Public Health 2003; 117: 49-53. (Abstract)

15. Kılıçaslan B, Altınkaynak S, Selimoğlu MA. Atatürk Üniversitesi Tıp Fakültesi Çocuk Sağlığı ve Hastalıkları Polikliniğine getirilen çocuklarda hepatit B virüsü serolojisi. Çocuk Dergisi 2004; 4: 37-41. (Abstract) 
16. Arabacı $F$, Demirli $H$. Van'da 6-10 yaş grubu çocuklarda hepatit A ve B seroprevalansı. İnfeksiyon Dergisi 2005; 19: 457-60. (Abstract) / (PDF)

17. Karslıgil T, Sırmatel F, Uygur O, Özçubukçu R. Değişik gruplarda hepatit B virusu yüzey antijeni ve antikor pozitifliğinin yaş gruplarına göre dağılımı. Anadolu Tıp Dergisi 2003; 5: 1-5.

18. Şahin Y, Aydın D. Altı yaş altı çocuklarda hepatit B seroprevalansı. Firat Tıp Dergisi 2005; 10: 169-72. (PDF)

19. Tsatsralt-Od B, Takahashi M, Endo K, et al. Prevalence of hepatitis $\mathrm{B}, \mathrm{C}$, and delta virus infections among children in Mongolia: progress in childhood immunization. J Med Virol 2007; 79: 1064-74. (Abstract)

20. Ali SA, Donahue RM, Qureshi H, Vermund SH. Hepatitis B and hepatitis $C$ in Pakistan: prevalence and risk factors. Int $J$ Infect Dis 2009; 13: 9-19. (Abstract) / (Full Text) / (PDF)

21. Lin JB, Lin DB, Chen SC, Chen PS, Chen WK. Seroepidemiology of hepatitis $A, B, C$, and $E$ viruses infection among preschool children in Taiwan. J Med Virol 2006; 78: 18-23. (Abstract)

22. Al-Tawfiq JA, Anani AA. Profile of viral hepatitis A, B, and C in a Saudi Arabian hospital. Med Sci Monit 2008; 14: 52-6. (Abstract)

23. Quoilin S, Hutse V, Vandenberghe $\mathrm{H}$, et al. A population-based prevalence study of hepatitis $A, B$ and $C$ virus using oral fluid in Flanders, Belgium. Eur J Epidemiol 2007; 22: 195-202. (Abstract)

24. Al-Faleh FZ, Al-Jeffri M, Ramia S, et al. Seroepidemiology of hepatitis B virus infection in Saudi children 8 years after a mass hepatitis B vaccination programme. J Infect 1999; 38: 167-70. (Abstract) / (Full Text) / (PDF)
25. Sümer Z, Sümer H, Bakıcı MZ, Koç S. Cumhuriyet Üniversitesi Tıp Fakültesi kan merkezi verici kanlarının HBsAg, antiHCV, anti-HIV ve sifiliz seropozitifliği yönünden değerlendirilmesi. Viral Hepatit Dergisi 2001; 2: 330-2.

26. Kaya S, Poyraz Ö, Sümer Z, Özdemir L. Cumhuriyet Üniversitesi Tıp Fakültesi Hastanesi kan merkezine başvuran vericilerde saptanan infeksiyon etkenlerinin 5 yıllık peryotta retrospektif olarak değerlendirilmesi. VII. Ulusal viral hepatit kongresi kitabı, Viral Hepatitle Savaşım Derneği, 2004: 116.

27. Barak S, Yoldaşan E, Kılıç B. Adana ili yarı kırsal alanda yaşayan 10 yaş üzeri kișilerde $\mathrm{HBsAg}$ ve anti-HCV prevalansı. Infeksiyon Dergisi 2002; 16: 133-40.

28. Kurt H, Battal İ, Memikoğlu O, Yeşilkaya A, Tekeli E. Ankara bölgesinde sağlıklı bireylerde HAV, HBV ve HCV prevalansının yaş ve cinsiyete göre dağılımı. Viral Hepatit Dergisi 2003; 8: 88-106.

29. Akbulut HH, Çelik İ, Güngör $S$, Aydınoğlu H, Doğan Y. Elazığ ili 7-14 yas arası çocuklarda hepatit virüsleri seropozitiflikleri. Viral Hepatit Dergisi 2001; 1: 266-9.

30. Bör $O$, Us $T$, Akgün $N$, Akgün $Y$. Cocuklarda hepatit $A, B$ ve $C$ virüsleri seromarker sonuçları. Viral Hepatit Dergisi 2000; 2: 102-4.

31. Sahin K, Durmaz R, Özerol iH. Farklı sosyoekonomik ve yas gruplarındaki sağlıklı kişilerde anti-HCV pozitifliğinin araștırıması. V. Ulusal viral hepatit kongresi kongre kitabı, Viral Hepatitle Savaşım Derneği, 2000: P-C12.

32. Taşyaran MA, Akdağ R, Akyüz M, Kaya A, Ceviz N, Yılmaz S. Erzurum bölgesi çocuklarında parenteral bulaşan hepatit virüslerinin seroprevalansı. Klimik Dergisi 1994; 7: 76-8.

33. Wu TC, Chuang WL, Dai CY, et al. Hepatitis $C$ virus infection among children in aboriginal areas in Taiwan. Trans R Soc Trop Med Hyg 2008; 102: 935-8. (Abstract) 